\title{
KEPEMIMPINAN DAN PROMOSI JABATAN DAN KINERJA KARYAWAN (STUDI KASUS: PERUSAHAAN UMUM (PERUM) JAMINAN KREDIT INDONESIA KANTOR CABANG PEKANBARU)
}

\author{
YAYU KUSDIANA \\ STIE Mahaputra Riau \\ Jl. Paus No. 52 Pekanbaru 28282 \\ Telp. (0761) 859050 \\ E-mail : yayu0677@gmail.com
}

\begin{abstract}
The Influence of Leadership and Job Promotion on employee performance performance at Perum Jamkrindo Pekanbaru Branch Office. The purpose of this study was to determine the effect of Leadership and Job Promotion on employee performance performance at Perum Jamkrindo Pekanbaru Branch Office. The method in this study uses quantitative descriptive methods. This study uses a census population, which is all population samples. The sample in this study was 44. The hypothesis test consisted of the F test, and the T test. Based on the F test results it was proven that leadership and promotion positions had an influence with a significant level of 0.00 on employee performance at the Perum Jamkrindo Pekanbaru Branch Office, indicated by Fcount greater than Ftable (59.878> 3.23) with a significant level of $0.000<0.05$, while the test results of the coefficient of determination $(R 2)$ obtained an adjusted $R$ square value of 0.733 or $73.3 \%$, which means that leadership and promotion have an influence on employee performance at Perum Jamkrindo Pekanbaru Branch Office and the remaining $26.7 \%$ are influenced by other factors. Based on the T test it is proven that leadership has a significant effect on employee performance at the Perum Jamkrindo Pekanbaru Branch Office indicated by a tcount greater than ttable (3,636> 1,68195) and influential promotion with a significant level of 0,000 on employee performance at Perum Jamkrindo Pekanbaru Branch Office indicated with a tcount greater than t table (8.538> 1.68195).
\end{abstract}

Keywords: Leadership, Position Promotion, Employee Performance 


\begin{abstract}
ABSTRAK
Pengaruh Kepemimpinan Dan Promosi Jabatan Terhadap Kinerja kinerja karyawan pada Perum Jamkrindo Kantor Cabang Pekanbaru. Tujuan penelitian ini untuk mengetahui pengaruh Kepemimpinan Dan Promosi Jabatan Terhadap Kinerja kinerja karyawan pada Perum Jamkrindo Kantor Cabang Pekanbaru. Metode dalam penelitian ini menggunakan metode deskriptif kuantitatif. Penelitian ini menggunakan populasi sensus, yaitu seluruh jumlah populasi dijadikan sampel. Sampel dalam penelitian ini sebanyak 44. Uji hipotesis terdiri dari uji F, dan uji T. Berdasarkan hasil uji $\mathrm{F}$ terbukti bahwa kepemimpinan dan jabatan promosii memiliki pengaruh dengan tingkat signifikan 0,00 terhadap kinerja karyawan pada Perum Jamkrindo Kantor Cabang Pekanbaru, ditunjukkan dengan nilai $F_{\text {hitung }}$ lebih besar dari $F_{\text {tabel }}(59,887$ $>3,23$ ) dengan tingkat signiikan $0,000<0.05$, sedangkan hasil uji koefisien determinasi $\left(\mathrm{R}^{2}\right)$ diperoleh nilai adjusted $\mathrm{R}$ square sebesar 0,733 atau $73,3 \%$ yang artinya kpeemimpinan dan promosi jabatan memiliki pengaruh terhadap kinerja karyawan pada Perum Jamkrindo Kantor Cabang Pekanbaru dan sisanya sebesar 26,7\% dipengaruhi oleh faktor lain. Berdasarkan uji $\mathrm{T}$ terbukti bahwa kepemimpinan berpengaruh signifikan terhadap kinerja karyawan pada Perum Jamkrindo Kantor Cabang Pekanbaru ditunjukkan dengan nilai $t_{\text {hitung }}$ lebih besar dari $t_{\text {tabel }}(3,636>$ 1,68195) dan promosi jabatan berpengaruh dengan tingkat signifikan 0,000 terhadap kinerja karyawan pada Perum Jamkrindo Kantor Cabang Pekanbaru ditunjukkan dengan nilai $t_{\text {hitung }}$ lebih besar dari $t_{\text {tabel }}(8,538>1,68195)$.
\end{abstract}

\title{
Kata Kunci : Kepemimpinan, Promosi Jabatan, Kinerja Karyawan
}

\section{PENDAHULUAN}

\section{Latar Belakang}

Kinerja merupakan hasil kerja secara kualitas dan kuantitas yang dicapai oleh seorang karyawan dalam melaksanakan tugasnya sesuai dengan tanggung jawab yang diberikan kepadanya dalam mencaai tujuan organisasi yang nantinya akan dijadikan dasar penilaian atas tercapai atau tidaknya tujuan dari organisasi tersebut.

Di dalam pencapaian target dan tujuan organisasi tersebut tidak mudah, baik organisasi milik pemerintah atau milik swasta oleh sebab itu peran manajemen sumber daya manusia sangatlah penting artinya dalam hal mengupayakan agar tenaga kerja mau dan mampu memberikan prestasi kerjanya sebaik mungkin. 
Karyawan merupakan sumber daya yang sangat penting bagi kelangsungan hidup perusahaan, sehingga perlu mendapat perhatian hal - hal yang berkaitan dengan kinerja karyawan dalam rangka mencapai tujuan perusahaan.

Dengan demikian setiap perusahaan harus memperhatikan tingkat kemampuan kepemimpinan dan komunikasi yang baik dan benar kepada seluruh karyawannya sehingga tercipta iklim kekeluargaan yang

baik yang pada akhirnya dapat meningkatkan kinerja karyawan. Peningkatan kepemimpinan yang efektif dan benar merupakan salah satu segi dari keefektifan kerja karyawan.

Selain itu, untuk mencapai tujuan perusahaan tersebut maka sumber daya manusia perlu di beri dorongan yang cukup agar dapat termotivasi perlu diberikan penghargaan berupa pengembangan karir, promosi, dan pemberian bonus yang dapat memberikan kepuasan tersendiri bagi karyawan sehingga dapat meningkatkan kinerja karyawan tersebut. Salah satu strategi yang harus di implementasikan oleh pihak manajemen adalah membuat perencanaan dan pengembangan karir bagi seluruh karyawan selama mereka bekerja di perusahaan. Untuk sebagian besar karyawan kepastian karir merupakan hal yang sangat penting karena mereka akan tahu posisi tertinggi yang akan mereka capai, sehingga mereka akan termotivasi dan terus berusaha meningkatkan kemampuan serta loyal terhadap perusahaan.

Dalam hal kepemimpinan dan pengembangan karir atau promosi jabatan di Kantor Jamkrindo Cabang Pekanbaru masih perlu dikelola dengan baik. Pimpinan perusahaan memiliki karakter overprotektif dan tempramental sehingga membuat karyawan sulit untuk menyesuaikan diri terhadap pimpinannya, pimpinan datang terlambat sementara disisi lain karyawan diwajibkan untuk melaksanakan disiplin dan mematuhi peraturan perusahaan salah satunya mematuhi jadwal masuk dan keluar kantor, pimpinan lalai dalam hal controling serta perhatian mereka terhadap kondisi bawahannya. Perusahaan memiliki penilaian tertentu terhadap pelaksanaan promosi karyawan namun disisi timbulnya sifat kecemburuan anatar karyawan yang memperoleh promosi, adanya karyawan lain yang merasa tersaingi, sehingga hal tersebut dapat mempengaruhi kinerja karyawan.

Hasil penelitian yang dilakukan Mulyono (2013) dengan menunjukkan bahwa untuk kepemimpinan dan promosi jabatan tidak berpengaruh signifikan terhadap kinerja sedangkan menurut Jayusman dan Siti (2012), terdapat pengaruh signifikan secara simultan antara kepemimpinan dan promosi jabatan terhadap kinerja karyawan.

Penelitian dari Simanjuntak (2015), Fatmawati (2013), Elisawati (2012), menyatakan bahwa promosi jabatan berpengaruh signifikan terhadap kinerja karyawan. Sedangkan hasil penelitian yang dilakukan Umam menyebutkan bahwa promosi jabatan tidak berpengaruh terhadap kinerja karyawan.

\section{Rumusan Masalah}


Berdasarkan latar belakang dirumuskan masalah sebagai berikut:

1. Apakah kepemimpinan berpengaruh terhadap kinerja karyawan pada Perum Jamkrindo Kantor Cabang Pekanbaru?

2. Apakah promosi jabatan berpengaruh terhadap kinerja karyawan pada Perum Jamkrindo Kantor Cabang Pekanbaru?

3. Apakah kepemimpinan dan promosi jabatan berpengaruh terhadap kinerja karyawan pada Perum Jamkrindo Kantor Cabang Pekanbaru?

\section{Tujuan Penelitian}

Tujuan dari penelitian ini adalah:

1. Untuk mengetahui pengaruh kepemimpinan berpengaruh terhadap kinerja karyawan pada Perum Jamkrindo Kantor Cabang Pekanbaru.

2. Untuk mengetahui pengaruh promosi jabatan berpengaruh terhadap kinerja karyawan pada Perum Jamkrindo Kantor Cabang Pekanbaru.

3. Untuk mengetahui pengaruh kepemimpinan dan promosi jabatan berpengaruh terhadap kinerja karyawan pada Perum Jamkrindo Kantor Cabang Pekanbaru.

\section{KERANGKA TEORI}

\section{Kinerja}

Moeheriono (2012), menyatakan bahwa kinerja atau performance merupakan hasil kerja yang dapat dicapai oleh seseorang atau kelompok orang dalam

suatu organisasi baik secara kuantitatif maupun kualitatif, sesuai dengan wewenang dan tanggung jawab masing-masing, ddalam upaya mencapai tujuan organisasi bersangkutan secara legal, tidak melanggar hukum dan sesuai dengan moral maupun etika.

Mangkunegara (2013), menyatakan kinerja (prestasi kerja) adalah hasil kerja secara kualitas dan kuantitas yang dicapai oleh seorang karyawan dalam melaksanakan tugasnya sesuai dengan tanggung jawab yang diberikan kepadanya.

Menurut Robbins (2015), kinerja merupakan suatu hasil yang dicapai oleh pekerja dalam pekerjaannya menurut kriteria tertentu yang berlaku untuk suatu pekerjaan.

Mulyadi (2015), mengemukakan bahwa kinerja merupakan sebagai hasil-hasil fungsi pekerjaan/kegiatan seseorang atau kelompok dalam suatu organisasi yang dipengaruhi oleh berbagai faktor untuk mencapai tujuan organisasi dalam periode waktu tertentu.

Menurut Gibson, Ivancevich dan Donnely, 2010 dalam Priansa (2016), menyatakan bahwa faktor - faktor yang mempengaruhi kinerja adalah : 
1. Variabel Individu, meliputi kemampuan dan keterampilan baik fisik maupun mental, latar belakang, keluarga, tingkat sosial dan pengalaman, demografi, umur, asal usul dan jenis kelamin.

2. Variabel Pisikologis, meliputi presepsi, sikap, kepribadian, belajar, motivasi, promosi dan karir.

3. Variabel Organisasi, meliputi sumber daya, kepemimpinan, imbalan, struktur dan desain pekerjaan.

\section{Kepemimpinan}

Menurut Koontz dan O’donnel dalam Moeheriono (2012), kepemimpinan sebagai proses mempengaruhi sekelompok orang sehingga mau bekerja dengan sungguh-sungguh untuk meraih tujuan kelompok.

Menurut Feriyanto dan Shynta (2015), pemimpin adalah suatu lakon/peran dalam sistem tertentu, karenanya seseorang dalam peran formal belum tentu memiliki keterampilan kepemimpinan dan belum tentu mampu memimpin.

Menurut Uha (2015), kepemimpinan adalah:

1. Kepemimpinan adalah kemampuan dan seni memperoleh hasil melalui kegiatan dengan mempengaruhi orang lain dalam rangka pencapaian tujuan yang telah ditentukan sebelumnya.

2. Kepemimpinan merupakan kemampuan mempengaruhi orang lain dalam hal para bawahan sehingga mau dan mampu melakukan kegiatan tertentu meskipun secara pribadi hal tersebut mungkin tidak disenanginya.

Menurut Hasibuan (2016), kepemimpinan adalah cara seorang pemimpin mempengaruhi perilaku bawahan, agar mereka mau bekerjasama dan bekerja secara produktif untuk mencapai tujuan organisasi.

Keith Davis dalam Thoha Miftah (2013), merumuskan empat sifat yang tampaknya mempunyai pengaruh terhadap keberhasilan kepemimpinan organisasi:

1. Kecerdasan.

2. Kedewasaan dan keluasan hubungan sosial.

3. Motivasi diri dan dorongan berprestasi.

4. Sikap - sikap hubungan kemanusiaan.

\section{Promosi Jabatan}

Hasibuan (2013), mengatakan promosi adalah perpindahan yang memperbesar autority dan responsibility karyawan ke jabatan yang lebih tinggi di dalam satu organisasi sehingga kewajiban, hak, status, dan penghasilan semakin besar.

Siagian (2008), mengemukakan apabila seorang karyawan dipindahkan dari satu pekerjaan ke pekerjaan lain yang tanggung jawabnya lebih besar, tingkatannya dalam hierarki jabatan lebih tinggi dan penghasilannya pun lebih besar pula. 
Menurut Priansa (2016), promosi jabatan dapat dipahami sebagai pemberian tugas, tanggung jawab, serta wewenang baru yang lebih tinggi dan luas kepada karyawan dengan diringi oleh kenaikan kompensasi dan unsur penunjang lainnya bagi karyawan sehingga selain beban kerjanya meningkat, kesejahteraan yang diperoleh oleh karyawan juga meningkat dengan mempertimbangkan fakor - faktor:

1. Kinerja dan prestasi.

2. Senioritas.

3. Pengalaman.

4. Kompetensi.

Menurut Hasibuan (2013), menjelaskan tujuan dari promosi jabatan adalah sebagai berikut:

1. Untuk memberikan pengakuan, jabatan dan imbalan jasa yang semakin besar kepada karyawan yang berprestasi kerja tinggi.

2. Dapat menimbulkan kepuasan dan kebanggan pribadi, status social yang semakin tinggi dan penghasilan yang semakin besar.

3. Untuk merangsang agar karyawan lebih bergairah bekerja, berdisiplin tinggi dan memperbesar produktivitas kerjanya.

4. Untuk menjamin stabilitas kekaryawanan dengan direalisasikan promosi kepada karyawan dengan dasar dan pada waktu yang tepat serta penilaian yang jujur.

5. Kesempatan promosi Jabatan dapat menimbulkan keuntungan berantai (mutilier effect) dalam perusahaan

karena timbulnya lowongan berantai.

6. Memberikan kesempatan kepada karyawan untuk mengembangkan kreativitas dan inovasinya yang lebih baik demi keuntungan optimal perusahaan.

7. Untuk menambah dan memperluas pengetahuan serta pengalaman kerja para karyawan dan ini merupakan daya dorong bagi karyawan lainnya.

8. Untuk mengisi kekosongan jabatan karena pejabatnya berhenti. Agar jabatan itu tidak lowong maka dipromosikan karyawan lainnya.

9. Karyawan yang dipromosikan kepada jabatan yang tepat, semangat, kesenangan dan ketenangannya dalam bekerja semakin meningkat sehingga produktivitas kerjanya juga meningkat.

10. Untuk mempermudah penarikan pelamar, sebab dengan adanya kesempatan promosi merupakan daya dorong serta perangsang bagi pelamar-pelamar untuk memasukkan lamarannya.

11. Promosi akan memperbaiki status karyawan dari karyawan sementara menjadi karyawan tetap setelah lulus dalam masa percobaannya.

\section{Kerangka Pemikiran}

Penelitian ini terdiri dari 3 variabel yaitu: (1) Kepemimpinan $\left(\mathrm{X}_{1}\right)$, (2) Promosi Jabatan $\left(\mathrm{X}_{2}\right)$, (3) Kinerja Pegawai (Y). 


\section{Pengaruh Kepemimpinan terhadap Kinerja Pegawai}

Sebuah organisasi bila memiliki seorang pimpinan yang handal akan lebih mampu mengantisipasi permasalahan organisasi dan mengambil peluang dari perubahan yang ada sehingga dapat mengarahkan organisasi sampai pada tujuannya. Karena itulah kepemimpinan menjadi salah satu faktor yang bisa mempengaruhi kinerja pegawai.

Menurut Koontz dan O'donnel dalam Moeheriono (2012:381) Kepemimpinan sebagai proses mempengaruhi sekelompok orang sehingga mau bekerja dengan sungguh-sungguh untuk meraih tujuan kelompok.

Robbins (2015), mengemukakan bahwa kepemimpinan (leadership) adalah kemampuan untuk mempengaruhi suatu kelompok menuju pencapaian sebuah visi atau tujuan yang ditetapkan.

Hasil penelitian yang dilakukan Djuremi, dkk (2016), Kusumawati (2015), Lina (2014), Hasan (2013), Sumarni (2011) dan Wiranata (2011) kepemimpinan memiliki pengaruh yang signifikan terhadap kinerja karyawan.

\section{Pengaruh Promosi Jabatan terhadap Kinerja Pegawai}

Jika kesempatan untuk dipromosikan relatif kecil atau hampir tidak ada maka gairah kerja, semangat kerja, disiplin, dan prestasi kerja karyawan akan menurun. Namun, jika ada kesempatan bagi setiap karyawan dipromosikan berdasarkan asas keadilan dan objektivitas, karyawan akan terdorong bekerja giat, disiplin, dan berprestasi kerja sehingga sasaran perusahaan dapat dicapai (Hasibuan, 2012).

Menurut Priansa (2016), salah satu faktor penyemangat karyawan dalam bekerja adalah adanya promosi jabatan. Organisasi harus mampu dan memberikan kesempatan kepada siapapun karyawan yang ada didalam organisasi untuk meningkatkan karirnya melalui program promosi.

Penelitian dari Simanjuntak (2015), Fatmawati (2013), Elisawati (2012), menyatakan bahwa promosi jabatan berpengaruh signifikan terhadap kinerja karyawan.

\section{Pengaruh Kepemimpinan dan Promosi Jabatan terhadap Kinerja Pegawai}

Menurut Priansa (2016), promosi jabatan dapat dipahami sebagai pemberian tugas, tanggung jawab, serta wewenang baru yang lebih tinggi dan luas kepada karyawan dengan diringi oleh kenaikan kompensasi dan unsur penunjang lainnya bagi karyawan sehingga selain beban kerjanya meningkat, kesejahteraan yang diperoleh oleh karyawan juga meningkat dengan mempertimbangkan fakor - faktor:

5. Kinerja dan prestasi.

6. Senioritas.

7. Pengalaman.

8. Kompetensi. 
Hasil penelitian yang dilakukan Mulyono (2013) dengan menunjukkan bahwa untuk kepemimpinan dan promosi jabatan tidak berpengaruh signifikan terhadap kinerja sedangkan menurut Jayusman dan Siti (2012), terdapat pengaruh signifikan secara simultan antara kepemimpinan dan promosi jabatan terhadap kinerja karyawan.

\section{Model Penelitian}

Dalam penelitian ini terdapat dua variabel, yaitu variabel bebas $(\mathrm{X})$ dan variabel terikat (Y). Variabel bebas merupakan variabel yang mempengaruhi atau yang menjadi sebab perubahannya atau timbulnya variabel terikat. Variabel bebas dalam penelitian adalah Kepemimpinan $\left(\mathrm{X}_{1}\right)$ dan Promosi Jabatan $\left(\mathrm{X}_{2}\right)$. Sedangkan variabel terikat merupakan variabel yang dipengaruhi atau yang menjadi akibat, karena adanya variabel bebas. variabel terikat dalam penelitian ini adalah Kinerja (Y).

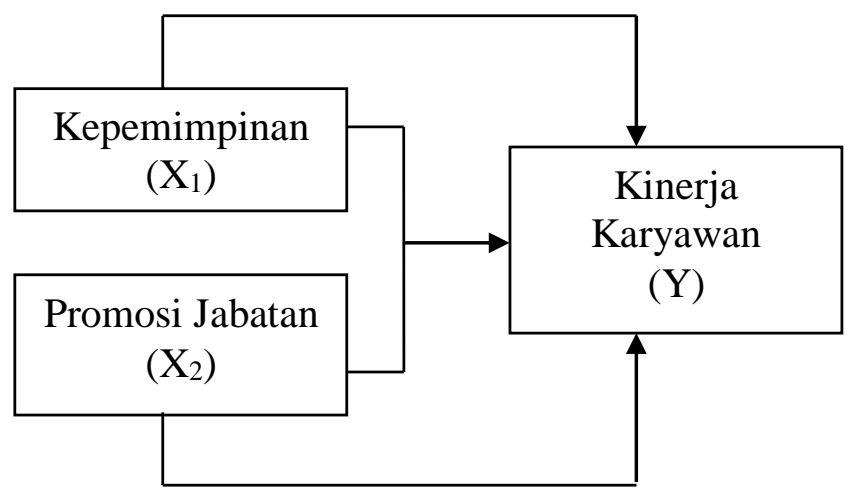

Gambar 2.1: Kerangka PemikiranHipotesis

Berdasarkan rumusan masalah dan tinjauan pustaka diatas maka hipotesis yang diajukan penelitian ini adalah :

Ha1: Pengaruh kepemimpinan $\left(\mathrm{X}_{1}\right)$ terhadap kinerja karyawan pada Perum Jamkrindo Kantor Cabang Pekanbaru. (Y).

Ha2: Pengaruh jabatan promosi $\left(\mathrm{X}_{2}\right)$ terhadap kinerja karyawan pada Perum Jamkrindo Kantor Cabang Pekanbaru (Y).

Ha3: Pengaruh kepemimpinan $\left(\mathrm{X}_{1}\right)$ dan jabatan promosi $\left(\mathrm{X}_{2}\right)$ terhadap kinerja karyawan pada Perum Jamkrindo Kantor Cabang Pekanbaru (Y).

\section{Metodelogi Penelitian}

\section{Objek Penelitian}

Penelitian dilakukan pada Jamkrindo Kantor Cabang Pekanbaru yang beralamat Jln Jendral Sudirman No. 150, sedangkan waktu penelitian akan dilakukan dari bulan Maret 2017 sampai dengan Desember 2017. 


\section{Populasi dan Sampel}

Populasi dalam penelitian ini adalah seluruh karyawan Jamkrindo Kantor Cabang Pekanbaru.

Menurut Sugiyono, (2014), sampel merupakan bagian populasi yang akan diteliti atau sebagian jumlah dari karakteristik yang dimiliki oleh populasi. Sampel merupakan himpunan bagian dari unit populasi.

Teknik pengambilan sampel pada penelitian dengan menggunakan sensus, yaitu teknik pengambilan sampel yang dilakukan dari populasi menjadi sampel penelitian, sehingga sampel pada penelitian sebesar 44 orang sampel atau responden.

\section{Teknik Pengumpulan Data}

Metode pengumpulan data melalui kuesioner dan wawancara langsung pada seluruh karyawan Jamkrindo Kantor Cabang Pekanbaru tentang berbagai informasi/data yang diperlukan dengan menggunakan skala likert.

Skala likert digunakan untuk mengukur sikap, pendapat dan persepsi seseorang atau sekelompok orang tentang fenomenal sosial. Dengan skala likert, maka variabel yang diukur dan dijabarkan menjadi indikator variabel.

Sebagai titik tolak untuk menyusun item - item instrument yang dapat berupa pernyataan dan pertanyaan. Jawaban setiap item yang menggunakan skala likert mempunyai gradiasi dan sangat positif sampai sangat negatif (Sugiyono, 2011).

Kemudian untuk mengetahui rata - rata jawaban responden digunakan interval kelas, interval kelas dapat dirumuskan dengan rumus :

Adapun skala yang digunakan adalah seagai berikut ini :

$\begin{array}{lllll}\text { 1. Sangat Setuju } & \text { skor } & 5 & \text { dengan range } & (4,21-5,00) \\ \text { 2. Setuju } & \text { skor } & 4 & \text { dengan range } & (3,41-4,20) \\ \text { 3. Netral } & \text { skor } & 3 & \text { dengan range } & (2,61-3,40) \\ \text { 4. Tidak Setuju } & \text { skor } & 2 & \text { dengan range } & (1,81-2,60) \\ \text { 5. Sangat Tidak Setuju } & \text { skor } & 1 & \text { dengan range } & (1,00-1,80)\end{array}$

Definisi Operasional Variabel

Tabel 1: Definisi Oerasional Variabel 


\begin{tabular}{|c|c|c|c|c|}
\hline No & $\begin{array}{l}\text { Variabel } \\
\text { Penelitian }\end{array}$ & Defenisi & Indikator & $\begin{array}{c}\text { Skala } \\
\text { Pengukuran }\end{array}$ \\
\hline 1. & $\begin{array}{l}\text { Kepemimpinan } \\
\qquad\left(\mathrm{X}_{1}\right)\end{array}$ & $\begin{array}{l}\text { Pemimpin adalah } \\
\text { suatu lakon/peran } \\
\text { dalam sistem } \\
\text { tertentu, karenanya } \\
\text { seseorang dalam } \\
\text { peran formal belum } \\
\text { tentu memiliki } \\
\text { keterampilan } \\
\text { kepemimpinan dan } \\
\text { belum tentu mampu } \\
\text { memimpin. } \\
\text { (Feriyanto dan } \\
\text { Shynta, 2015) }\end{array}$ & $\begin{array}{l}\text { 1. Kecerdasan. } \\
\text { 2. Kedewasaan dan keluasan } \\
\text { hubungan sosial. } \\
\text { 3. Motivasi diri dan dorongan } \\
\text { berprestasi } \\
\text { 4. Sikap - sikap hubungan } \\
\text { kemanusiaan. }\end{array}$ & Likert \\
\hline 2. & $\begin{array}{l}\text { Promosi Jabatan } \\
\qquad\left(\mathrm{X}_{2}\right)\end{array}$ & $\begin{array}{l}\text { Promosi adalah } \\
\text { perpindahan yang } \\
\text { memperbesar } \\
\text { authority dan } \\
\text { responbility } \\
\text { karyawan ke jabatan } \\
\text { yang lebih tinggi di } \\
\text { dalam satu } \\
\text { organisasi sehingga } \\
\text { kewajiban, hak, } \\
\text { status, dan } \\
\text { penghasilan semakin } \\
\text { besar (Edwin B } \\
\text { Flipo dalam } \\
\text { Hasibuan, 2011) }\end{array}$ & $\begin{array}{l}\text { 1. Lama Bekerja. } \\
\text { 2. Usia. } \\
\text { 3. Latar Belakang }\end{array}$ & Likert \\
\hline 3. & Kinerja (Y) & $\begin{array}{l}\text { Kinerja (prestasi } \\
\text { kerja) adalah hasil } \\
\text { kerja secara kualitas } \\
\text { dan kuantitas yang } \\
\text { dicapai oleh seorang }\end{array}$ & $\begin{array}{l}\text { 1. Kualitas Kerja. } \\
\text { 2. Kuantitas Kerja. } \\
\text { 3. Hasil Kerja. }\end{array}$ & Likert \\
\hline
\end{tabular}




\begin{tabular}{|l|l|l|l|}
\hline & karyawan dalam & & \\
melaksanakan & & \\
tugasnya sesuai & & \\
dengan tanggung & jawab yang & & \\
diberikan & kepadanya. & & \\
Mangkunegara & & & \\
& $(2013)$ & & \\
\hline
\end{tabular}

Sumber: Olahan data (2017).

\section{Regresi Liniear Berganda}

Analisis linear regresi berganda adalah hubungan secara linear antara dua atau lebih variabel bebas Budaya Organisasi $\left(\mathrm{X}_{1}\right)$ dan Pengawasan $\left(\mathrm{X}_{2}\right)$ dengan variabel terikat Disiplin Kerja Pegawai (Y). Model regresi berganda dikembangkan untuk melakukan estimesi/prediksi nilai variabel dependen $(\mathrm{Y})$ dengan menggunakan lebih dari satu variabel indenpenden $\left(\mathrm{X}_{1}, \mathrm{X}_{2}, \mathrm{X}_{3}\right.$,dst). Persamaan regresi linear berganda adalah :

$$
\begin{aligned}
& \mathbf{Y = a}+\mathbf{b}_{1} \mathbf{X}_{1}+\mathbf{b}_{2} \mathbf{X}_{2}+\mathbf{e} \\
& \text { Keterangan : } \\
& \mathrm{Y} \quad=\text { Variabel terikat (Disiplin Kerja Pegawai) } \\
& \mathrm{a} \quad=\text { Konstanta } \\
& \mathrm{b}_{1} \mathrm{~b}_{2}=\text { Koefisien Berganda } \\
& \mathrm{e} \quad=\text { Error } \\
& \mathrm{X}_{1} \quad=\text { Budaya Organisasi } \\
& \mathrm{X}_{2} \quad=\text { Pengawasan }
\end{aligned}
$$

\section{Hasil Penelitian dan Pembahasan}

\section{Analisis Regresi Linier Berganda}

Persamaan regresi berganda digunakan untuk menggambarkan model hubungan antar variabel bebas dengan variabel terikatnya. Persamaan regresi ini memuat nilai konstanta atau intercept nilai koefisien regresi atau slope dan variabel bebasnya. Berdasarkan hasil penelitian, persamaan dalam analisis regresi linier berganda dalam penelitian ini adalah :

\section{Tabel 2: Hasil Regresi Linier Berganda}




\section{Hasil Uji Regresi Linier Berganda}

\section{Coefficients $^{\mathrm{a}}$}

\begin{tabular}{|c|c|c|}
\hline \multirow[b]{2}{*}{ Model } & \multicolumn{2}{|c|}{ Unstandardized Coefficients } \\
\hline & B & Std. Error \\
\hline 1 (Constant) & 14.02 & 1.740 \\
\hline Kepemimpinan & .16 & .044 \\
\hline Promosi Jabatan & .45 & .053 \\
\hline
\end{tabular}

a. Dependent Variable: Kinerja Karyawan

Sumber : Data Olahan Spss Berdasarkan Tabel 2 tersebut dapat diketahui

persamaan regresi sebagai berikut:

\section{Persamaan Regresi Berganda:}

$\mathbf{Y}=\mathbf{a}+\mathbf{b}_{1} \mathbf{X}_{1}+\mathbf{b}_{2} \mathbf{X}_{2}+\mathbf{e}$

$Y=14,025+0,160 X_{1}+0,456 X_{2}+e$

Arti angka - angka dalam persamaan regresi diatas adalah :

1. Nilai a $=14,025$ menunjukkan bahwa apabila variabel kepemimpinan $\left(X_{1}\right)$ dan promosi jabatan $\left(\mathrm{X}_{2}\right)$ sebesar 0,160 maka variabel kinerja $(\mathrm{Y})$ masih ada sebesar 14,025 satuan.

2. Nilai $\mathrm{b} 1=0,160$ menunjukkan bahwa apabila variabel kepemimpinan $\left(\mathrm{X}_{1}\right)$ meningkat sebesar 1 satuan, maka variabel kinerja (Y) akan mengalami peningkatan sebesar 0,160 satuan

3. Nilai b2 $=0,456$ menunjukkan bahwa apabila variabel promosi jabatan $\left(\mathrm{X}_{2}\right)$ Meningkat sebesar 1 satuan, maka variabel kinerja (Y) akan mengalami peningkatan sebesar 0,456 satuan.

4. Standar error (e) merupakan variabel acak dan mempunyai distribusi probabilitas yang mewakili semua faktor yang mempunyai pengaruh terhadap Y tetapi tidak dimasukan dalam persamaan.

\section{Hasil Uji Hipotesis}


Pengujian ini dilakuakan untuk mengetahui besarnya pengaruh variabel indepeden secara sendiri - sendiri terhadap variabel dependen. Pengujian ini dilakukan dengan membandingkan t yang didapat dari perhitungan dengan nilai t yang ada pada table $t$ dengan tingkat kesalahan $(\alpha)$ sebesar 5\% dengan kriteria sebagai berikut:

a. Bila $t_{H i t u n g}>t_{\text {Tabel }}$ maka, Ho ditolak dan Hipotesa alternative (Ha) diterima.

b. Bila $t_{\text {Hitung }}<\mathrm{t}_{\text {Tabel }}$ maka, Ho diterima dan Hipotesa alternative (Ha) ditolak.

Berikut adalah hasil pengujian regresi linier sederhana dalam penelitian ini didapat t-statistik sebagai berikut :

\section{Tabel 3}

\section{Hasil Uji Secara Parsial (Uji T)}

Coefficients $^{\text {a }}$

\begin{tabular}{|c|c|c|c|c|c|c|}
\hline \multirow{2}{*}{\multicolumn{2}{|c|}{ Model }} & \multicolumn{2}{|c|}{$\begin{array}{c}\text { Unstandardized } \\
\text { Coefficients }\end{array}$} & \multirow{2}{*}{$\begin{array}{c}\begin{array}{c}\text { Standardized } \\
\text { Coefficients }\end{array} \\
\text { Beta }\end{array}$} & \multirow[b]{2}{*}{$\mathrm{t}$} & \multirow[b]{2}{*}{ Sig. } \\
\hline & & B & Std. Error & & & \\
\hline \multirow[t]{3}{*}{1} & (Constant) & 14.025 & 1.740 & & 8.060 & .000 \\
\hline & $\begin{array}{l}\text { Kepemimpina } \\
\mathrm{n}\end{array}$ & .160 & .044 & .304 & 3.636 & .001 \\
\hline & $\begin{array}{l}\text { Promosi } \\
\text { Jabatan }\end{array}$ & .456 & .053 & .714 & 8.538 & .000 \\
\hline
\end{tabular}

a. Dependent Variable: Kinerja Karyawan

\section{Sumber: Data Olahan Spss}

Berdasarkan tabel diatas maka dapat diketahui sebagai berikut:

1. Pengaruh variabel Kepemimpinan $\left(\mathrm{X}_{1}\right)$ terhadap variabel Kinerja (Y) menunjukan nilai $t_{\text {hitung }}(3,636)>t_{\text {tabel }}(1,68195)$ dengan nilai signifikasi yang dihasilkan sebesar $(0,001)$ berada dibawah 0,05, maka, Ho ditolak dan Hipotesa alternative (Ha) diterima.

2. Pengaruh variabel promosi jabatan $\left(\mathrm{X}_{2}\right)$ terhadap variabel Kinerja (Y) menunjukan nilai $t_{\text {hitung }}(8,538)>t_{\text {tabel }}(1,68195)$ dengan nilai signifikasi yang dihasilkan sebesar $(0,000)$ berada dibawah 0,05, maka, Ho ditolak dan Hipotesa alternative (Ha) diterima.

\section{Uji Secara Simultan (Uji F)}


Pengujian $\mathrm{f}_{\text {hitung, }}$ untuk mengetahui apakah terdapat pengaruh yang signifikan atau tidak secara simultan dilakukan dengan uji $f$ statistik pada $\alpha=0.05(5 \%)$. Apabila $\mathrm{f}_{\text {hitung }}<\mathrm{f}_{\text {tabel }}$ atau signifikan ( $\left.\mathrm{sig}\right)<\alpha=0.05$ maka $\mathrm{H}_{0}$ : diterima dan $\mathrm{H}_{\mathrm{a}}$ ditolak. Apabila $\mathrm{f}_{\text {hitung }}>\mathrm{f}_{\text {tabel }}$ atau signifikan ( $\left.\mathrm{sig}\right)<\alpha=0.05$ maka $\mathrm{H}_{0}$ : ditolak dan $\mathrm{H}_{\mathrm{a}}$ diterima. Berdasarkan uji regersi yang dilakukan, diperoleh nilai $\mathrm{f}_{\text {hitung }}$ pada tabel sebagai berikut:

Tabel 4

Uji Secara Simultan (Uji F)

ANOVA ${ }^{b}$

\begin{tabular}{|ll|l|ll|}
\hline & & & & \\
Model & & F & Sig. & \\
\hline 1 & Regression & 59.887 & & \\
& Residual & & & \\
& Total & & & \\
\hline
\end{tabular}

a. Predictors: (Constant), Promosi Jabatan, Kepemimpinan

b. Dependent Variable: Kinerja Karyawan

\section{Sumber : Data Olahan SPSS}

Dari tabel diatas diketahui $f_{\text {hitung }}$ sebesar 59,887 dengan signifikansi 0,000. Diketahui $\mathrm{f}_{\text {table }}$ dengan persamaan $\mathrm{n}-\mathrm{k}-1=44-2-1=41$ dapat diperoleh dari $\mathrm{f}_{\text {tabel }}$ statistik sebesar $(3,23)$. Dengan demikian diketahui $f_{\text {hitung }}(59,887)>f_{\text {tabel }}(3,23)$ dengan Sig. $(0,000)<0,05$. Artinya kepemimpinan dan promosi jabatan memiliki pengaruh terhadap kinerja karyawan Kantor Jamkrindo Cabang Pekanbaru.

\section{Koefisien Determinasi $\left(\mathbf{R}^{2}\right)$}

Koefesien determinasi digunakan untuk melihat kemampuan variabel independen dalam menerangkan variabel dependen, dimana nilai $\mathrm{R}$ Square yang mendekati satu maka variabel independen memberikan hampir semua informasi yang dibutuhkan untuk memprediksi variasi variabel dependen.

Hasil koefesien determinasi antara kepemimpinan dan promosi jabatan terhadap kinerja dapat dilihat hasilnya pada tabel berikut:

\section{Tabel 5}

\section{Koefisien Determinasi $\left(\mathbf{R}^{2}\right)$}




\begin{tabular}{|l|r|r|r|r|r|}
\hline & \multicolumn{9}{|c|}{ Model Summary $^{\mathrm{b}}$} \\
\hline Model & $\mathrm{R}$ & $\mathrm{R}$ Square & $\begin{array}{c}\text { Adjusted R } \\
\text { Square }\end{array}$ & $\begin{array}{c}\text { Std. Error of the } \\
\text { Estimate }\end{array}$ & Durbin-Watson \\
\hline 1 & $.863^{\mathrm{a}}$ & .745 & .733 & 1.25827 & 2.197 \\
\hline
\end{tabular}

a. Predictors: (Constant), Promosi Jabatan, Kepemimpinan

b. Dependent Variable: Kinerja Karyawan

\section{Sumber : Data Olahan SPSS}

Dari tabel 5 di atas dapat diketahui nilai Nilai adjusted Adjusted R Square $\left(\mathrm{R}^{2}\right)$ sebesar 0,733 atau 73,3\% ini berarti variabel kinerja karyawan dijelaskan oleh nilai kepemimpinan dan promosi jabatan sisanya $26,7 \%$ dipengaruhi oleh variabel lain yang tidak digunakan dalam penelitian ini.

Pembahasan

Pengaruh Kepemimpinan Terhadap

Kinerja Karyawan Pada Perusahaan

Umum (Perum) Jaminan Kredit

Indonesia Kantor Cabang Pekanbaru.

Kepemimpinan berpengaruh terhadap kinerja karyawan pada Perusahaan Umum (Perum) Jaminan Kredit Indonesia Kantor Cabang Pekanbaru. Hal ini sesuai dengan pendapat Simamora (2005), mengemukakan kinerja sangat ditentukan oleh 3 (tiga) faktor yaitu :

1. Faktor Individual yang terdiri dari: Kemampuan dan keahlian, Latar belakang, Demografi.

2. Faktor psikologis yang terdiri dari: Persepsi, Attitude, Personality, Pembelajaran, Motivasi, Karir dan Promosi Jabatan.

3. Faktor organisasi yang terdiri dari: Sumber daya, Kepemimpinan, Penghargaan, Struktur, Job design.

Hal ini juga sesuai dengan hasil penelitian yang dilakukan oleh Wiranata (2011), kepemimpinan berpengaruh terhadap kinerja karyawan

\section{Pengaruh Promosi Jabatan Terhadap}

Kinerja Karyawan Pada Perusahaan

Umum (Perum) Jaminan Kredit

\section{Indonesia Kantor Cabang Pekanbaru.}

Promosi jabatan berpengaruh terhadap kinerja karyawan pada Perusahaan Umum (Perum) Jaminan Kredit Indonesia Kantor Cabang Pekanbaru, hal ini sesuai dengan pendapat Hasibuan (2012) yaitu jika kesempatan untuk dipromosikan relatif kecil atau hampir tidak ada maka gairah kerja, semangat kerja, disiplin, dan prestasi kerja karyawan akan menurun. Namun, jika ada kesempatan bagi setiap karyawan dipromosikan berdasarkan asas keadilan dan objektivitas, karyawan akan terdorong bekerja giat, disiplin, dan berprestasi kerja sehingga sasaran perusahaan dapat dicapai. 
Penelitian ini juga di dukung oleh penelitian yang dilakukan antaranya Jayusman dan Siti (2012), Wiwin dkk (2016) yang hasil penelitiannya promosi jabatan berpengaruh terhadap kinerja karyawan.

\section{Kesimpulan dan Saran}

\section{Kesimpulan}

Berdasarkan dari hasil penelitian ini diperoleh beberapa kesimpulan secara ringkas disajikan sebagai berikut :

1. Kepemimpinan dan promosi jabatan memiliki pengaruh yang signifikan terhadap kinerja karyawan pada Perusahaan Umum (Perum) Jaminan Kredit Indonesia Kantor Cabang Pekanbaru.

2. Variabel yang memiliki pengaruh paling dominan pada kinerja Perusahaan Umum (Perum) Jaminan Kredit Indonesia Kantor Cabang Pekanbaru adalah faktor variabel promosi jabatan $\left(\mathrm{X}_{2}\right)$, hal ini bisa dilihat dari hasil uji regresi linear berganda dimana diperoleh nilai b2 sebesar $=0,456$. Dan jauh dibandingkan dari variabel kepemimpinan $\left(\mathrm{X}_{1}\right)$ dimana diperoleh nilai b1 sebesar $=0,160$ satuan.

3. Hasil uji $\mathrm{T}$, menunjukkan bahwa kepemimpinan $\left(\mathrm{X}_{1}\right)$ terhadap variabel kinerja (Y) menunjukan nialai $t_{\text {hitung }}(3,636)>t_{\text {tabel }}(1,68195)$ dengan nilai signifikasi yang dihasilkan sebesar $(0,001)$ berada dibawah 0,05 , maka, Ho ditolak dan Hipotesa alternative $(\mathrm{Ha})$ diterima. Pengaruh variabel promosi jabatan $\left(\mathrm{X}_{2}\right)$ terhadap variabel Kinerja $(Y)$ menunjukan nilai $t_{\text {hitung }}(8,538)>t_{\text {tabel }}(1,68195)$ dengan nilai signifikasi yang dihasilkan sebesar $(0,000)$ berada dibawah 0,05 , maka, Ho ditolak dan Hipotesa alternatif (Ha) diterima.

4. Berdasarkan dari uji $\mathrm{F}$ bahwa kedua variabel bebas tersebut berpengaruh terhadap

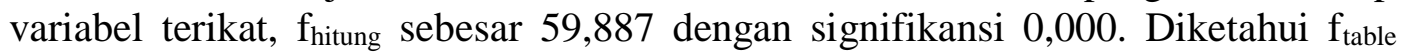
dengan persamaan $\mathrm{n}-\mathrm{k}-1=44-2-1=41$ dapat diperoleh dari $\mathrm{f}_{\text {tabel statistik }}$ sebesar $(3,23)$. Dengan demikian diketahui $f_{\text {hitung }}(59,887)>f_{\text {tabel }}(3,23)$ dengan Sig. $(0,000)<0,05$. Artinya kepemimpinan dan promosi jabatan memiliki pengaruh terhadap kinerja karyawan Kantor Jamkrindo Cabang Pekanbaru.

5. Hasil perhitungan uji koefisien determinasi $\left(\mathrm{R}^{2}\right)$ diketahui nilai Adjusted $\mathrm{R}$ Square adalah sebesar 0,733 atau 73,3\% yang berarti kepemimpinan dan promosi jabatan memiliki pengaruh yang signifikan terhadap kinerja karyawan dan sisanya sebesar $26,7 \%$ dipengaruhi oleh variabel lain yang tidak ada dalam penelitian ini.

\section{Saran}

Berdasarkan kesimpulan diatas, penulis juga memberikan beberapa saran dalam penelitian ini sebagai berikut :

1. Meskipun secara keseluruhan kepemimpinan yang ada pada Perusahaan Umum (Perum) Jaminan Kredit Indonesia Kantor Cabang Pekanbaru sudah baik, namun beberapa indikator masih tetap harus diperhatikan. Yakni dalam hal pendelegasian 
wewenang, pengelolaan emosi, memberikan kesempatan kepada pegawainya untuk dapat mengambil keputusan yang berkaitan dalam penyelesaian tugas yang diberikan.

2. Demikian pula halnya pada promosi jabatan, meskipun secara keseluruhan sudah baik, namun ada beberapa indikator yang harus diperhatikan. Yakni manajemen harus juga memperhatikan situasi - situasi seperti kondisi karyawan, kebutuhan pisikologis, pelaksaan promosi yang sesuai dengan ketentuan perusahaan dan menghindari kebutuhan individual sehingga semangat dan gairah kerja mereka dalam bekerja dapat berjalan secara optimal.

3. Dan diharapkan kepada seluruh karyawan agar dapat bekerja sesuai standar kualitas kerja yang telah ditetapkan oleh organisasi dan hasil kerja dapat dicapai dengan lebih baik lagi, serta beban kerja yang diberikan tidak melebihi kemampuan karyawan.

\section{DAFTAR PUSTAKA}

Djuremi, dkk. 2016. Pengaruh Lingkungan Kerja, Budaya Organisasi dan Kepemimpinan terhadap Kinerja Pegawai pada Dinas Pasar Kota Semarang. Journal of Management. Volume 2, Nomor 2.

Elisawati. 2012. Pengaruh Promosi Jabatan dan Rekan Sekerja Terhadap Kinerja Karyawan Pada Perkebunan Lubuk Raja PT. Serikat Putra Pelelawan. Skripsi.Universitas Islam Negeri Sultan Syarif Kasim Riau: Pekanbaru.

Fatmawati, Puji 2013. Pengaruh Promosi Jabatan Terhadap Kinerja Pegawai Di Dinas Pendapatan Pengelolaan Keuangan dan Asset (DPPKA) Kabupaten Kulon Progo. Tugas Akhir. Universitas Yogyakarta.

Feriyanto, Andri dan Shyta Triana. 2015. Pengantar Manajemen (3 in 1). Penerbit MEDIATERA: Kebumen

Jayusman dan Siti Khotimah, 2012. Pengaruh Kepemimpinan, Komunikasi, Motivasi, Pengembangan karir Dan Promosi Jabatan Terhadap Kinerja Pegawai Kantor Secretariat Daerah Kabupaten Kota Waringin Barat. Skripsi. Fakultas Ekonomi Universitas Antakusuma Pangkalan Bun: Pangkalan.

Kusumawati, Ajeng Retno. 2015. Pengaruh Kepemimpinan terdadap Peningkatan Kinerja Pegawai pada Bank Muamalat Indonesia. Skripsi. Universitas Syarif Hidayatullah: Jakarta.

Mangkunegara, A.A. Anwar Prabu. 2013. Manajemen Sumber Daya Manusia Perusahaan. Cetakan Kesebelas. PT. Remaja Rosdakarya Offset. Bandung. 
Moeheriono. 2012. Pengukuran Kinerja “Berbasis Kompetensi”. Edisi Revisi. PT. Raja Grafindo Persada. Jakarta.

Mulyadi, Deddy. 2015. Perilaku Organisasi dan Kepemimpinan Pelayanan. Alfabeta. Bandung.

Mulyono. 2013. Pengaruh Kepemimpinan, Komunikasi,Motivasi,Pengembangan Karir, Dan Promosi Jabatan Terhadap Kinerja Pegawai Kantor Sekretariat Daerah Kabupaten Sukoharjo. Skripsi, STIE AUB: Surakarta.

Simanjuntak, Winda Yuliarta, 2015. Peranan Promosi Jabatan Terhadap Kinerja Karyawan pada PT. Riau Media Grafika/Tribun Pekanbaru. Skripsi. Fakultas Studi Administrasi Bisnis FISIP. Universitas Riau: Pekanbaru

Umam, Moh Khoirul. 2015. Pengaruh Insentif dan Promosi Jabatan Terhadap Kinerja Karyawan PT. BPR Syariah Artha Mas Abadi Pati. Skripsi, Fakultas Ekonomi dan Bisnis Islam, Universitas Islam Negeri Walisongo: Semarang.

Hasan, Zuhri Oktaviani. 2013. Pengaruh Kepemimpinan terhadap Kinerja Pegawai pada Kantor Perwakilan Badan Kependudukan dan Keluarga Berencana Nasional Provinsi Gorontalo. Skripsi. Prodi Manajemen.

Hasibuan, Malayu S.P. 2013. Manajemen Sumber Daya Manusia. Penerbit PT. Bumi Aksara Cetakan ke Tujuh Belas: Jakarta.

Hasibuan, H. Melayu S.P. 2016. Manajemen Sumber daya Manusia. Edisi Revisi. Cetakan Kesembilan Belas. PT. Bumi Aksara. Jakarta.

Lina, Dewi. 2014. Analisis pengaruh kepemimpinan dan budaya Organisasi terhadap kinerja pegawai dengan sistem Reward sebagai variabel moderating Jurnal Riset Akuntasi dan Bisnis. Volume 14, Nomor 1.

Priansa, Donni Juni. 2016. Perencanaan dan Pengembangan SDM. Penerbit CV. ALFABETA: Bandung.

Robbins, Stephen P. 2015. Perilaku Organisasi. Cetakan Ketiga. Salemba Empat. Jakarta.

Sumarni, Dede. 2011. Pengaruh Kepemimpinan dan Budaya Organisasi Terhadap Kinerja Karyawan (Studi Kasus pada PDAM Tirta Moedal Semarang). Skripsi, Prodi Manajemen, Fakultas Ekonomi, Universitas Negeri Semarang. 
Siagian, Sondang P. 2008. Manajemen Sumber Daya Manusia. PT Bumi Aksara: Jakarta.

Sugiyono. 2011. Statistika untuk Penelitian. Alfabeta: Bandung.

Sugiyono. 2012. Statistika untuk Penelitian. Alfabeta: Bandung.

Uha, H. Ismail Nawawi. 2015. Budaya Organisasi Kepemimpinan dan Kinerja “Proses Terbentuk, Tumbuh Kembang, Dinamika, dan Kinerja Organisasi”. Cetakan Kedua. Prenadamedia Group. Jakarta.

Wiranata, Anak, Agung. 2011. Pengaruh Kepemimpinan Terhadap Kinerja Dan Stres Karyawan (Studi Kasus : Cv. Mertanadi). Skripsi. Fakultas Teknik, Universitas Udayana: Denpasar.

Wiwin, Agustian dkk. 2016. Pengaruh Promosi Jabatan Dan Seleksi Penerimaan Karyawan Terhadap Kinerja Karyawan PT. Pgascom Palembang.Skripsi. Universitas Bina Darma: Palembang. 